\title{
MACRO- AND MICRO- ESTHETICS ANALYSIS AMONG EGYPTIAN DENTAL STUDENTS
}

\author{
Azza F. Osman ${ }^{1 *} B D S$, Yousreya A. Shalaby ${ }^{2} P h D$, Maha M. Elboksomaty ${ }^{3}$ \\ $P h D$, Naguib A. El Fawal ${ }^{4} P h D$
}

\begin{abstract}
INTRODUCTION: Esthetics has great importance in restorative dentistry. It is essential to obtain standardized anthropometric data to increase both treatment and esthetic success. A harmonious facial appearance is the most essential aim of successful treatment in the esthetic field. It is a steady fact that human faces contrast from each other based on gender, race, and ethnicity.

OBJECTIVES: This study was aimed to analyze the macro-esthetics of the face and the micro-esthetics of the maxillary anterior teeth to determine the normative values of Egyptian adults and investigate possible gender differences.

MATERIALS AND METHODS: The sample size was 126 Egyptian dental students (63 males and 63 females) aged between (18-24) years. All students were clinically examined, and then extra-oral and intra-oral photographs were taken. The measurements of faces and teeth were obtained using 2D Adobe Photoshop ${ }^{\circledR}$ CS5 software. Descriptive statistics were applied to the measured parameters and independent samples ttest was used to assess gender differences.

RESULTS: The results showed that for the linear and vertical facial measurements (macro-esthetic appearance), the males have larger facial dimensions than females with highly significant gender differences. While for most of the maxillary anterior teeth proportions (micro-aesthetic appearance), the females have larger proportions than males with statistically significant gender differences.

CONCLUSIONS: Based on 2D digital photogrammetry, the macro- and micro-esthetic appearances of Egyptian dental students were analyzed, and data were obtained. In most of the parameters, there were statistically significant gender differences $(\mathrm{P} \leq 0.05)$.

KEYWORDS: macro-esthetic; micro-esthetic appearance; Egyptian; digital photogrammetry; gender differences.
\end{abstract}

1-BDS,2006, Faculty of Dentistry, University of Science and Technology, Sudan.

2-Professor of Conservative Dentistry, Faculty of Dentistry, Alexandria University, Alexandria, Egypt.

3-Assistant Professor of Graphic Designing and Communication, Faculty of Arts, Alexandria University, Alexandria, Egypt.

4-Lecturer of Conservative Dentistry, Faculty of Dentistry, Alexandria University, Alexandria, Egypt.

*Corresponding author:

E-mail: azzafr.osman@yahoo.com

\section{INTRODUCTION}

Esthetics has become a vital portion of dentistry. Until the last twenty years, dentists considered esthetics to be less valuable than function, biology, and structure (1). These days, however, if the treatment plan doesn't include a clear vision of its esthetic effect on the patient, the results could be catastrophic. The esthetic aspect of a cosmetic restoration can be influenced by many factors related to the composition of an attractive smile, such as gingival architecture, midline position, amount of gingival display, clinical crown proportions, and tooth location; all of these are factors of interest in different dental specialties (2).

Actual tooth morphology and size are mentioned in dental literature, but conflicting data was presented $(3,4)$. Gender and racial differences within the average proportions of the maxillary anterior teeth were published, but the results were proper just for specific isolated communities $(5,6)$. Additionally, no correlation was observed between teeth morphology, size, and gender in some populations. These findings indicate the requirement of assessment of the anterior teeth to compare between different genders and racial groups (5).

Dental and facial esthetics has usually been determined in terms of macro and microelements (7). Macro esthetics correlates between the face, lips, gingiva, and teeth. Micro esthetics includes the esthetics of an individual tooth and also the observation that the color and form are attractive (8).
Image-based Research uses photography to collect and analyze data, as within the case with Anthropological studies, proposes a detailed guide regarding how we can approach a selected reality with a camera. Collier (1976) gives photography a key opening function to introduce us to a specific context within which photographs are bridges of communication between the photographer and his environment (9).

Hence, this study was aimed to determine the normative values of macro- and micro-esthetic appearance of Egyptian adults and detect the possible gender differences with the aid of photogrammetry and computer analysis. The null hypothesis was that there would be gender differences regarding macro- and micro- esthetic analysis in Egyptian individuals.

\section{MATERIALS AND METHODS}

Ethical Consideration: Approval was obtained from the Research Ethics Committee. All participants have signed the consent form. They were also assured of the confidentiality of the collected data, which will be available only to the study team and for study purposes and that their privacy will be respected. All participants were volunteers. They did not expect compensation, financial or otherwise, for the use of their photographs.

Sample: The study was performed at the Faculty of Dentistry, Alexandria University. Out of two hundred and fifty students 
examined, only one hundred and twenty-six (sixty-three males and sixty- three females) fitted the criteria of subject selection of this study.

Criteria of Sample Selection: 1) Egyptian dental students, age from 18 -24 years, 2) Class I occlusion classification, 3) Having complete upper and lower teeth regardless the third molar, 4) Absence of crowding, spacing, gingival recession or hyperplasia in the maxillary anterior teeth, 5) Absence of observed facial asymmetry, 6) No history of plastic surgery or facial trauma in the face. Whereas those with, 1) Restorations, prosthetic crowns or orthodontic appliance in the maxillary anterior teeth, 2) Malocclusion or oral habits like thumb sucking and tongue thrust, 3) Active periodontal diseases, 4) Developmental anomalies such as supernumerary teeth in the anterior region were excluded from the study $(8,10)$.

History and Clinical Examination: The participant's medical and dental history was taken. Extraoral and dental examination was done carefully in the dental chair.

Standardization of photographs: Frontal views were taken in natural head position. The participant's face was aligned in a camera's grid lines so that the Frankfurt horizontal line between the upper margin of the tragus and the infraorbital rim is usually aligned along one of the horizontal lines of the grid to avoid tilting of the head, this facilitates positioning of the patient in proper and uniform alignment and confirms the stability of photographs reproduction.(11)

The distance from the hairline to the outer corner of the eye was equal on both sides. A digital SLR Camera (Nikon D3400) was stabilized with the help of a heightadjustable tripod. The focal distance of all frontal facial photos was standardized one meter between the lens of the camera and the subject's face using a measuring tape. A ruler was fixed to each participant's forehead attached to a headband to calibrate the measurements. For intraoral photographs, the distance was $56 \mathrm{~cm}$ from the participant's face to the camera lens. Cheek retractors were used to display the maxillary anterior teeth, with the camera lens parallel to the labial surface of the teeth. AF-P $18-55 \mathrm{~mm}$ f/3.5 - 5.6G VR camera lens was used. (Fig.1)

Lightening: The lighting of the room was to mimic the natural light or sunlight. Flash and soft box rings were connected to the camera. A natural gray color background was used; it has been shown that it decreases glare-based eyestrain considerably. (12) (Fig.1)

The digital camera set-up: According to Nikon dental photography guide, Nikon D3400 - 24.2 Megapixels SLR Camera was set so that; images recorded in RAW format, exposure shooting mode manually, shutter speed $1 / 200$ s and ISO 200. For full-face images the aperture set to $f / 8$ and for intra-oral images aperture set to $\mathrm{f} / 32$.

Photographic exposure: Two photographs for each participant were taken; Frontal view at rest and Intra-oral view.

\section{Photographic analysis}

\section{1) The macro-esthetic appearance}

Frontal facial at rest photographs was analyzed using Adobe Photoshop ${ }^{\circledR}$ CS5 program software including:

Facial landmarks: (According to Milutinovic et al) (13) (Fig.2)

Nasion (n): The point in the midline of both the nasofrontal suture and the nasal root.
Inner canthus of the eye (Ic): The medial angle of the palpebral fissure.

Pupil of the eye (p): The center of the eye's iris.

Zygon (zy): Most lateral point of the zygomatic arch.

Alare of the nose (AL): Point located at the widest width of the nose at each lateral rim.

Subnasale (Sn): Point at which the nasal columella merges with upper cutaneous lip.

Chilion (Ch): Point located at an angle of the mouth.

Stomion (Sto): The midpoint of the labial fissure.

The Labrale Superius (LS): The midpoint at the skin border of the upper lip.

The Labrale Inferius (LI): The midpoint at the skin border of the lower lip.

Menton (Me): A most inferior point located at the soft tissue chin.

The Linear Facial Measurements: (According to Proffit et al.) (14) (Fig. 3)

Zygomatic width (zy-zy): The distance between the soft tissue zygion landmarks bilateraly.

Inter-canthal distance (ICD): The distance between the median canthi of the palpebral fissures.

Interpupillary width (IPW): The line between the centers of the two pupils.

Interalar width (IAW): The distance between the two soft tissue alare landmarks of the nose.

Mouth width (MW): The distance between the two angles of the mouth.

Vertical Facial Measurements: (According to Proffit et al.) (14) (Fig. 4)

Facial height (N-Me): The distance between the soft tissue nasion and menton landmarks.

Lower face height (Sn-Me): The distance between the soft tissue subnasale and menton landmarks.

Upper lip vermilion (ULV): The distance between the soft tissue labrale superius and stomion landmarks.

Lower lip vermilion (LLV): The distance between the soft tissue labrale inferius and stomion landmarks.

2) Maxillary anterior teeth measurements (15):

Intra-oral photographs were analyzed using Adobe Photoshop ${ }^{\circledR}$ CS5 program software including:

Mesiodistal width of each maxillary central incisors, lateral incisors, and canines was measured at the widest mesiodistal part of the tooth and parallel to the incisal edge (Fig. 5).

Combined mesiodistal width CMDW "the sum of mesiodistal widths of the maxillary central incisors, lateral incisors, and canines" was calculated.

.Total Maxillary Anterior Teeth Width "the distance between the tips of the maxillary right and left canines" was measured in a horizontal straight line (Fig. 5).

The height of central incisors was measured at the longest gingivo-incisal portion of the tooth (Fig. 6).

The height of the contact points were measured from the gingival convergence of the incisal embrasure to the incisal convergence of the gingival embrasure between maxillary anterior teeth (Fig. 6).

3) The Micro-esthetics appearance:

Using the maxillary anterior teeth measurements the microesthetic appearances were calculated includes:

The Golden Proportion: According to Levin (16) it could be defined as the proportion of sequential width of the upper anterior teeth. It should remain constant when proceeding 
distally from the midline. The golden proportion suggests that the width of the upper canine is $62 \%$ of the upper lateral width which is also $62 \%$ of the upper central width on the same side. The golden proportion was calculated as follow: For lateral incisor $=(\mathrm{MDW}$ of lateral incisor $) /(\mathrm{MDW}$ of central incisor) x 100

For canine $=(\mathrm{MDW}$ of canine $) /(\mathrm{MDW}$ of lateral incisor $) \mathrm{x}$ 100

The Golden Percentage: According to Snow (17), the width of each maxillary anterior tooth should be: $10 \%$ for the canines, $15 \%$ for the lateral incisors and, $25 \%$ for the central incisors of the CMDW. The golden percentage was calculated as follow:

Golden Percentage $=($ MDW central, lateral, canine )/(CMDW of maxillary anterior teeth ) x 100

Tooth Proportionality- Width to Height Ratio: Dental literature has several studies (18) that define a ratio of $80 \%$ as a golden standard for the width / height of the maxillary central incisors. The width to height ratio was calculated as follow:

Width-height ratio $=($ Width of the tooth $) /($ Height of the tooth) $\mathrm{x} 100$

Height of Contact Points Ratio: Contact points between the anterior teeth are where the teeth touched each other. According to Sarver (19), the standard ratio for contact point between the two central incisors is $50 \%$ of each central incisor height, for central/lateral incisors contact point is $40 \%$ of central incisor height, and for lateral incisor/canine contact point is $30 \%$ of central incisor height. This ratio was calculated as follow:

For central incisor $=($ Height of contact point between Centrals)/(Height of central incisor) x 100 .

For lateral incisor $=$ (Height of contact point (centrallateral))/(Height of central incisor) x 100.

For canine $=($ Height of contact point (lateral-canine $)) /($ Height of central incisor) x100.

\section{Reliability}

Reliability indicates the degree of agreement between raters. Ten of the photographs used in this study were selected randomly to assess the reliability and accuracy of the measurements. Both intra-examiner and inter-examiner reliability were tested, statistically non-significant differences were found.

\section{Statistical analysis}

Normality was checked using descriptive statistics, plots (histogram and box plot) and Kolmogorov Smirnov test. The normality of the data was approved, thus parametric tests were used. Micro-, Macro- esthetics, and maxillary teeth measurements were presented using mean and standard deviation.

Differences in Micro-, Macro- esthetics and maxillary teeth measurements between genders were assessed using independent t-test.

The significance level was set at $p \leq 0.05$. Data were analyzed using IBM SPSS statistical software (version25).

\section{RESULTS}

The results showed that all the parameters of macro-esthetic appearance were higher in males than females except for the upper and lower lip heights which were higher in females than males (Table 1). Regarding maxillary anterior teeth, results showed that males have higher measurements than females except for the mesiodistal width of lateral incisors and contact points which were higher in females (Table 2). In the micro-esthetic appearance, the females have larger proportions than males except for canines golden percentages and golden proportions (Table 3). On comparing both sexes, significant differences $(\mathrm{P}<0.005)$ have been found in all measurements except the Inter-canthal distance (ICD), Golden proportion of lateral incisors and, the Golden percentage of central and lateral incisors in both sides.

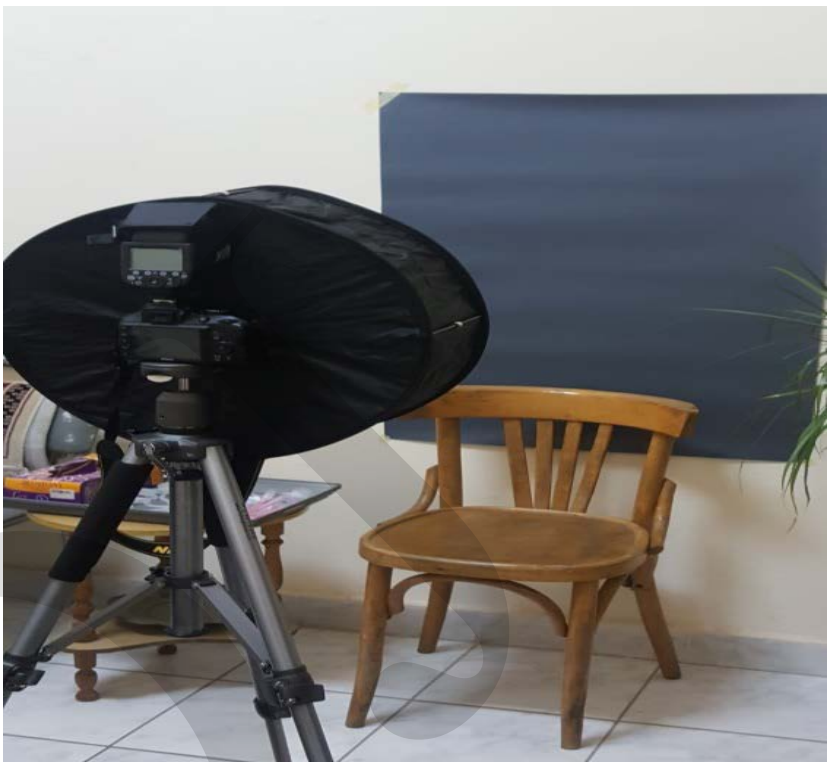

Fig. (1): (The mini studio) Nikon D3400 DSLR camera with 18-55mm VR lens, Godox VING V860IIN Flash for Nikon, collapsible magnetic ring softbox, adjustable tripod stand, and natural gray cardboard background

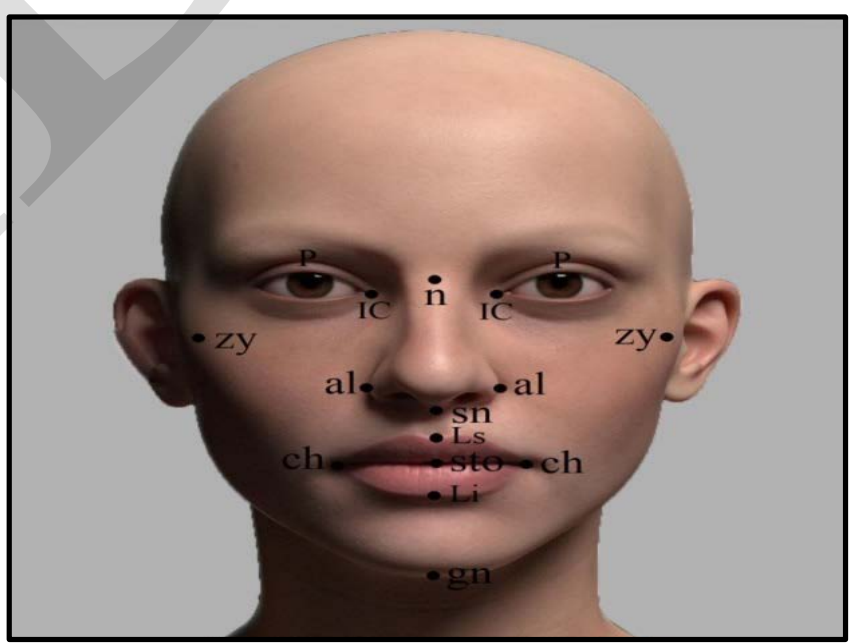

Fig. (2): Facial landmarks: Nasion (n), Inner canthus of the eye (Ic), Pupil (p), Zygoin (zy), Alare of the nose (AL), Subnasale (Sn), Chilion (Ch), Stomion (Sto), Labrale Superius (LS), Labrale Inferius (LI), and Menton (Me). 


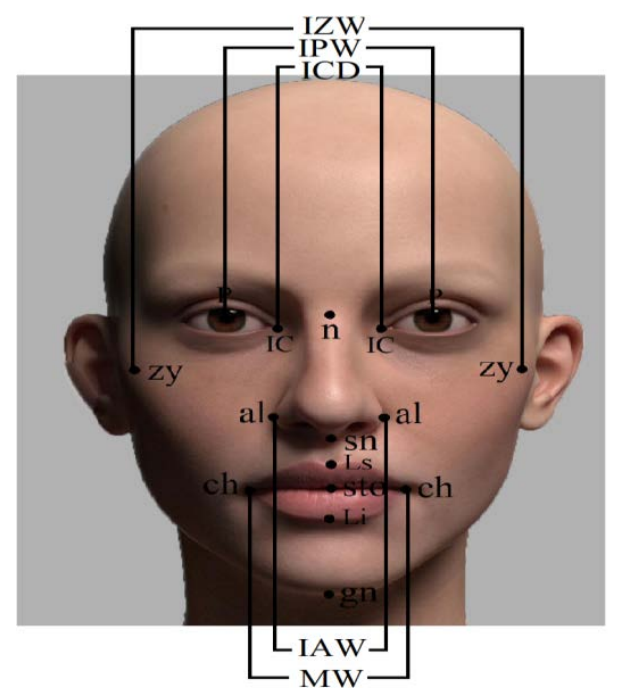

Fig. (3): Linear Facial Measurements: Zygomatic width (zyzy), Inter-canthal distance (IC-IC), Interpupillary width (PP), Interalar width (al-al), and Mouth width (ch-ch).

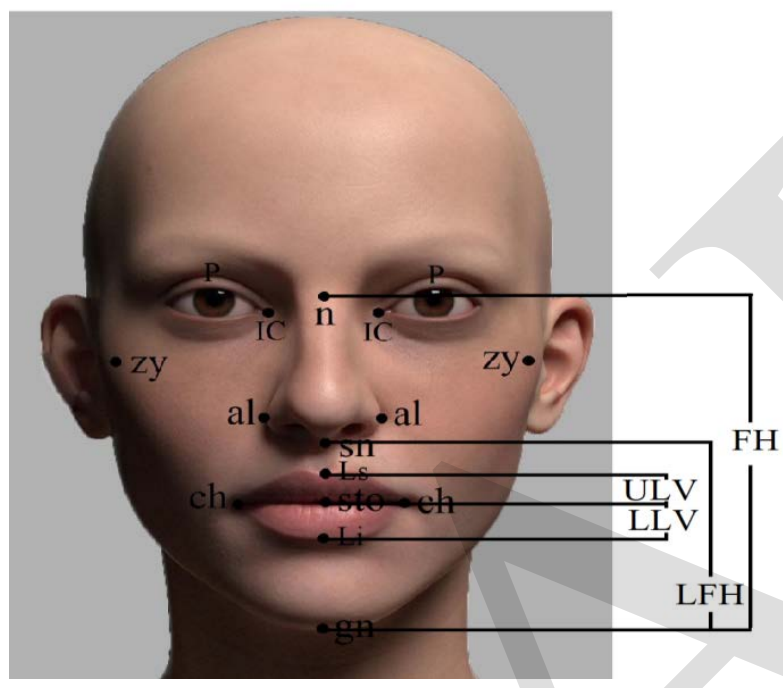

Fig. (4): Vertical Facial Measurements: Facial height (N$\mathrm{Me}$ ), Lower face height (Sn-Me), Upper lip vermilion (ULV), and Lower lip vermilion (LLV).

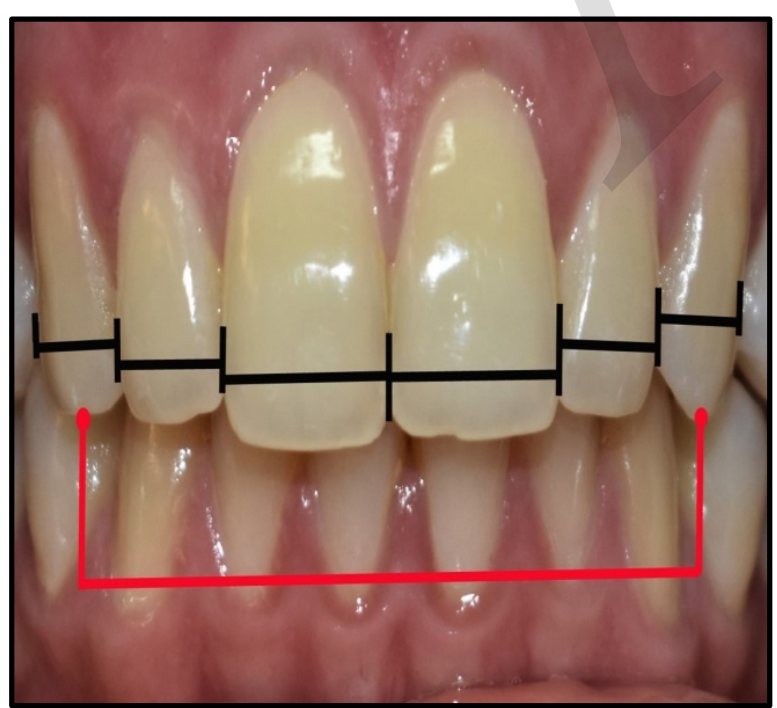

Fig. (5): The mesiodistal width of each of six maxillary anterior teeth (black); the total maxillary anterior teeth width (red).

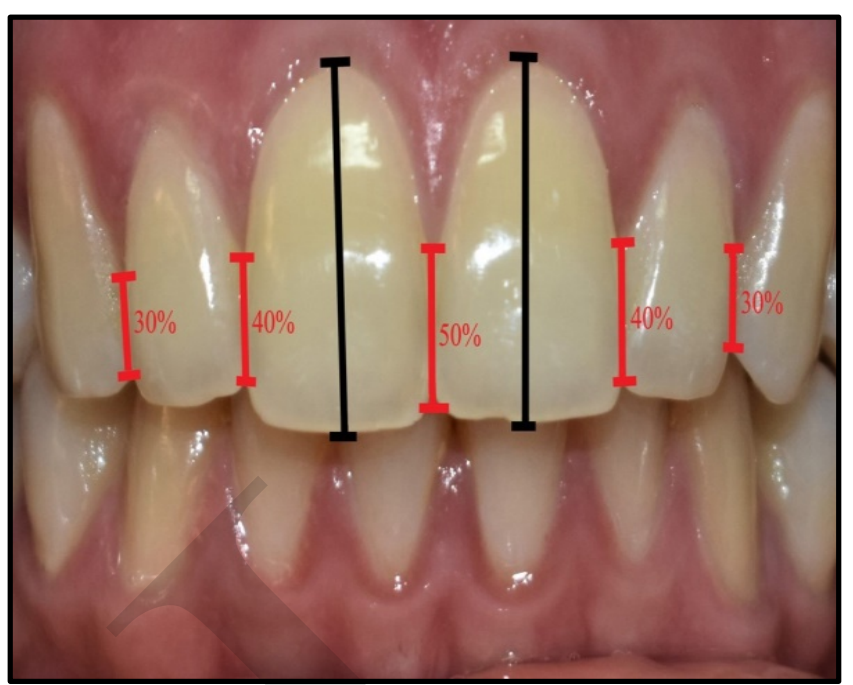

Fig. (6): The height of central incisors (black); the height of contact points (red).

Table (1): Descriptive statistics and gender differences in Macro-esthetic appearance

\begin{tabular}{|c|c|c|c|c|c|c|}
\hline \multirow{2}{*}{$\begin{array}{l}\text { Variabl } \\
\text { es }\end{array}$} & \multicolumn{2}{|c|}{$\begin{array}{l}\text { Males } \\
(\mathrm{N}=63)\end{array}$} & \multicolumn{2}{|c|}{$\begin{array}{l}\text { Females } \\
(\mathrm{N}=63)\end{array}$} & \multirow{2}{*}{$\begin{array}{l}\text { Gend } \\
\text { er } \\
\text { differ } \\
\text { ence }\end{array}$} & \multirow{2}{*}{$\begin{array}{l}\text { t-test } \\
\mathrm{p} \text { value }\end{array}$} \\
\hline & Mean & SD & Mean & SD & & \\
\hline IPW & 63.19 & 3.73 & 61.77 & 3.25 & 1.42 & $0.02 *$ \\
\hline ICD & 32.02 & 2.92 & 31.81 & 3.06 & 0.21 & 0.69 \\
\hline IAW & 40.38 & 2.97 & 36.30 & 2.31 & 4.08 & $\begin{array}{l}<<0.000 \\
1 *\end{array}$ \\
\hline MW & 50.64 & 2.92 & 48.75 & 4.12 & 1.89 & 0.004* \\
\hline zy-zy & $\begin{array}{l}124.5 \\
3 \\
\end{array}$ & 6.00 & $\begin{array}{l}119.5 \\
9 \\
\end{array}$ & 4.83 & 4.94 & $\begin{array}{l}<0.000 \\
1^{*}\end{array}$ \\
\hline N-Me & $\begin{array}{l}114.9 \\
9 \\
\end{array}$ & 6.11 & $\begin{array}{l}107.1 \\
6 \\
\end{array}$ & 4.84 & 7.83 & $\begin{array}{l}<0.000 \\
1^{*}\end{array}$ \\
\hline Sn-Me & 67.90 & 5.97 & 62.70 & 4.61 & 5.20 & $\begin{array}{l}<0.000 \\
1 *\end{array}$ \\
\hline ULV & 5.83 & 1.39 & 6.82 & 1.09 & -0.99 & $\begin{array}{l}<0.000 \\
1^{*}\end{array}$ \\
\hline LLV & 9.17 & 1.43 & 10.14 & 1.33 & -0.97 & $\begin{array}{l}<0.000 \\
1^{*}\end{array}$ \\
\hline
\end{tabular}

*Statistically significant difference at $p$ value $\leq 0.05$ SD: standard deviation

Table (2): Descriptive statistics and gender differences of maxillary anterior teeth measurements 


\begin{tabular}{|c|c|c|c|c|c|c|c|}
\hline \multirow{2}{*}{\multicolumn{2}{|c|}{ Variables }} & \multicolumn{2}{|c|}{$\begin{array}{l}\text { Males }(n=63 \\
\text { ) }\end{array}$} & \multicolumn{2}{|c|}{$\begin{array}{l}\text { Females(n= } \\
63)\end{array}$} & \multirow{2}{*}{$\begin{array}{l}\text { Mea } \\
\mathrm{n} \\
\text { diff } \\
\text { eren } \\
\text { ce }\end{array}$} & \multirow{2}{*}{$\begin{array}{l}\text { T test } \\
\text { P value }\end{array}$} \\
\hline & & $\begin{array}{l}\text { Mea } \\
\mathrm{n}\end{array}$ & SD & $\begin{array}{l}\text { Mea } \\
\mathrm{n}\end{array}$ & SD & & \\
\hline \multirow{6}{*}{$\begin{array}{l}\text { Mesio- } \\
\text { distal } \\
\text { width } \\
\text { (MDW) }\end{array}$} & $\begin{array}{l}\text { Right } \\
\text { Centra } \\
\text { l }\end{array}$ & 8.34 & 0.53 & 8.32 & 0.47 & 0.02 & 0.80 \\
\hline & $\begin{array}{l}\text { Right } \\
\text { Latera } \\
\text { l }\end{array}$ & 5.37 & 0.49 & 5.42 & 0.42 & $\overline{-}$ & 0.54 \\
\hline & $\begin{array}{l}\text { Right } \\
\text { Canin } \\
\text { e }\end{array}$ & 4.21 & 0.39 & 4.03 & $\begin{array}{l}(0.3 \\
8\end{array}$ & 0.18 & $0.01^{*}$ \\
\hline & $\begin{array}{l}\text { Left } \\
\text { Centra } \\
\text { l }\end{array}$ & 8.37 & 0.56 & 8.31 & 0.51 & 0.06 & 0.52 \\
\hline & $\begin{array}{l}\text { Left } \\
\text { Latera } \\
\text { l }\end{array}$ & 5.40 & 0.51 & 5.41 & 0.41 & $\overline{-}-01$ & 0.89 \\
\hline & $\begin{array}{l}\text { Left } \\
\text { Canin } \\
\mathrm{e} \\
\end{array}$ & 4.23 & 0.43 & 4.01 & 0.39 & 0.22 & $\begin{array}{l}<0.000 \\
1^{*}\end{array}$ \\
\hline \multicolumn{2}{|c|}{$\begin{array}{l}\text { Combined } \\
(\mathrm{MDW})\end{array}$} & $\begin{array}{l}36.0 \\
8 \\
\end{array}$ & 2.28 & $\begin{array}{l}35.5 \\
2 \\
\end{array}$ & 1.69 & 0.56 & 0.12 \\
\hline \multicolumn{2}{|c|}{$\begin{array}{l}\text { Total anterior } \\
\text { teeth (TAW) }\end{array}$} & $\begin{array}{l}33.0 \\
7 \\
\end{array}$ & 1.91 & $\begin{array}{l}32.6 \\
5 \\
\end{array}$ & 1.74 & 0.42 & 0.20 \\
\hline \multirow{5}{*}{$\begin{array}{l}\text { Height } \\
\text { of } \\
\text { contact } \\
\text { point }\end{array}$} & $\begin{array}{l}\text { Right } \\
\text { Canin } \\
\text { e- } \\
\text { Latera } \\
\text { l } \\
\end{array}$ & 2.24 & 0.37 & 2.44 & 0.34 & $\begin{array}{l}- \\
0.20\end{array}$ & $\begin{array}{l}<0.000 \\
1 *\end{array}$ \\
\hline & $\begin{array}{l}\text { Right } \\
\text { Latera } \\
\text { l } \\
\text { Centra } \\
\text { l }\end{array}$ & 2.73 & 0.47 & 2.87 & 0.47 & $\overline{-}-14$ & 0.09 \\
\hline & $\begin{array}{l}\text { Centra } \\
1- \\
\text { Centra } \\
1 \\
\end{array}$ & 3.43 & 0.57 & 3.53 & 0.49 & $\begin{array}{l}- \\
0.10\end{array}$ & 0.27 \\
\hline & $\begin{array}{l}\text { Left } \\
\text { Centra } \\
\text { l- } \\
\text { Centra } \\
1 \\
\end{array}$ & 2.70 & 0.48 & 2.89 & 0.48 & 0.19 & $0.03^{*}$ \\
\hline & $\begin{array}{l}\text { Left } \\
\text { Canin } \\
\text { e- } \\
\text { Latera } \\
\text { l } \\
\end{array}$ & 2.28 & 0.37 & 2.43 & 0.36 & $\overline{-}-15$ & $0.02 *$ \\
\hline \multirow{2}{*}{ Height } & $\begin{array}{l}\text { Right } \\
\text { central } \\
\text { incisor } \\
\end{array}$ & 9.86 & 0.71 & 9.62 & 0.77 & 0.25 & 0.06 \\
\hline & $\begin{array}{l}\text { Left } \\
\text { central } \\
\text { incisor }\end{array}$ & 9.90 & 0.71 & 9.62 & 0.78 & 0.28 & $0.04 *$ \\
\hline
\end{tabular}

*Statistically significant difference at $p$ value $\leq 0.05$

SD: standard deviation

Table (3): Descriptive statistics and gender differences in Micro-esthetic appearance

\begin{tabular}{|c|c|c|c|c|c|c|c|}
\hline \multirow{2}{*}{\multicolumn{2}{|c|}{ Variables }} & \multicolumn{2}{|c|}{$\begin{array}{l}\text { Males } \\
(\mathrm{N}=60)\end{array}$} & \multicolumn{2}{|c|}{$\begin{array}{l}\text { Females } \\
(\mathrm{N}=60)\end{array}$} & \multirow{2}{*}{$\begin{array}{l}\text { Mean } \\
\text { Differ } \\
\text { ence }\end{array}$} & \multirow{2}{*}{$\begin{array}{l}\text { t-test } \\
\mathrm{p} \\
\text { valu } \\
\mathrm{e} \\
\end{array}$} \\
\hline & & $\begin{array}{l}\text { Mea } \\
\mathrm{n}\end{array}$ & SD & $\begin{array}{l}\text { Mea } \\
\mathrm{n}\end{array}$ & SD & & \\
\hline \multirow{4}{*}{$\begin{array}{l}\text { Golden } \\
\text { Proporti } \\
\text { on }\end{array}$} & $\begin{array}{l}\text { Left } \\
\text { LI to } \\
\text { CI }\end{array}$ & $\begin{array}{l}64.6 \\
3\end{array}$ & 5.42 & $\begin{array}{l}65.1 \\
3\end{array}$ & 4.32 & -0.50 & 0.57 \\
\hline & $\begin{array}{l}\text { Right } \\
\text { LI to } \\
\text { CI }\end{array}$ & $\begin{array}{l}64.4 \\
8\end{array}$ & 5.70 & $\begin{array}{l}65.2 \\
0\end{array}$ & 4.75 & -0.72 & 0.44 \\
\hline & $\begin{array}{l}\text { Left } \\
\text { Ca to } \\
\text { LI }\end{array}$ & $\begin{array}{l}78.4 \\
9\end{array}$ & 8.21 & $\begin{array}{l}74.5 \\
1\end{array}$ & 8.01 & 3.98 & $\begin{array}{l}0.00 \\
7^{*}\end{array}$ \\
\hline & $\begin{array}{l}\text { Right } \\
\text { Ca to } \\
\text { LI }\end{array}$ & $\begin{array}{l}78.9 \\
8\end{array}$ & 7.60 & $\begin{array}{l}74.9 \\
8\end{array}$ & 7.80 & 4.00 & $\begin{array}{l}0.00 \\
4^{*}\end{array}$ \\
\hline \multirow{6}{*}{$\begin{array}{l}\text { Golden } \\
\text { Percenta } \\
\text { ge }\end{array}$} & $\begin{array}{l}\text { Left } \\
\text { CI to } \\
\text { CMD } \\
\text { W }\end{array}$ & $\begin{array}{l}23.2 \\
8\end{array}$ & 1.07 & $\begin{array}{l}23.3 \\
8\end{array}$ & 0.81 & -0.08 & 0.65 \\
\hline & $\begin{array}{l}\text { Right } \\
\text { CI to } \\
\text { CMD } \\
\text { W } \\
\end{array}$ & $\begin{array}{l}23.2 \\
0\end{array}$ & 0.89 & $\begin{array}{l}23.4 \\
2\end{array}$ & 0.78 & -0.20 & 0.19 \\
\hline & $\begin{array}{l}\text { Left } \\
\text { LI to } \\
\text { CMD } \\
W \\
W\end{array}$ & $\begin{array}{l}15.0 \\
3\end{array}$ & 0.94 & $\begin{array}{l}15.2 \\
0\end{array}$ & 0.78 & -0.17 & 0.28 \\
\hline & $\begin{array}{l}\text { Right } \\
\text { LI to } \\
\text { CMD } \\
\text { W } \\
\end{array}$ & $\begin{array}{l}14.9 \\
2\end{array}$ & 0.97 & $\begin{array}{l}15.2 \\
2\end{array}$ & $\begin{array}{l}0 \\
.88\end{array}$ & -0.30 & 0.07 \\
\hline & $\begin{array}{l}\text { Left } \\
\text { Ca to } \\
\text { CMD } \\
\text { W } \\
\end{array}$ & $\begin{array}{l}11.7 \\
4\end{array}$ & $\begin{array}{l}0 \\
.94\end{array}$ & $\begin{array}{l}11.2 \\
8\end{array}$ & 1.00 & 0.44 & $\begin{array}{l}0.01 \\
*\end{array}$ \\
\hline & $\begin{array}{l}\text { Right } \\
\text { Ca to } \\
\text { CMD } \\
\text { W }\end{array}$ & $\begin{array}{l}11.7 \\
0\end{array}$ & 0.99 & $\begin{array}{l}11.3 \\
4\end{array}$ & 0.95 & 0.35 & $\begin{array}{l}0.04 \\
*\end{array}$ \\
\hline \multirow{6}{*}{$\begin{array}{l}\text { Height } \\
\text { of } \\
\text { Contact } \\
\text { Point } \\
\text { Ratio }\end{array}$} & $\begin{array}{l}\text { Left } \\
\text { CI-CI }\end{array}$ & $\begin{array}{l}34.6 \\
3 \\
\end{array}$ & 5.46 & $\begin{array}{l}36.5 \\
5 \\
\end{array}$ & 4.72 & -1.92 & $\begin{array}{l}0.03 \\
*\end{array}$ \\
\hline & $\begin{array}{l}\text { Right } \\
\text { CI-CI }\end{array}$ & $\begin{array}{l}34.6 \\
0\end{array}$ & 5.62 & $\begin{array}{l}36.7 \\
7\end{array}$ & 5.04 & -2.17 & $\begin{array}{l}0.02 \\
*\end{array}$ \\
\hline & $\begin{array}{l}\text { Left } \\
\text { CI-LI }\end{array}$ & $\begin{array}{l}27.2 \\
2\end{array}$ & 3.94 & $\begin{array}{l}29.9 \\
8\end{array}$ & 4.00 & -2.76 & $\begin{array}{l}<0.0 \\
001 *\end{array}$ \\
\hline & $\begin{array}{l}\text { Right } \\
\text { CI-LI } \\
\end{array}$ & $\begin{array}{l}27.4 \\
5 \\
\end{array}$ & 4.12 & $\begin{array}{l}29.8 \\
3 \\
\end{array}$ & 4.58 & -2.38 & $\begin{array}{l}0.00 \\
3^{*} \\
\end{array}$ \\
\hline & $\begin{array}{l}\text { Left } \\
\text { LI-Ca }\end{array}$ & $\begin{array}{l}23.0 \\
0 \\
\end{array}$ & 3.17 & $\begin{array}{l}25.2 \\
4 \\
\end{array}$ & 3.25 & -2.25 & $\begin{array}{l}<0.0 \\
001 *\end{array}$ \\
\hline & $\begin{array}{l}\text { Right } \\
\text { LI-Ca }\end{array}$ & $\begin{array}{l}22.7 \\
3 \\
\end{array}$ & 3.22 & $\begin{array}{l}25.4 \\
1 \\
\end{array}$ & 3.35 & -2.68 & $\begin{array}{l}<0.0 \\
001 *\end{array}$ \\
\hline \multirow{2}{*}{$\begin{array}{l}\text { Width- } \\
\text { height } \\
\text { Ratio }\end{array}$} & $\begin{array}{l}\text { Left } \\
\text { CI } \\
\end{array}$ & $\begin{array}{l}84.7 \\
3 \\
\end{array}$ & 5.08 & $\begin{array}{l}86.9 \\
4 \\
\end{array}$ & 6.42 & -2.21 & $\begin{array}{l}0.03 \\
* \\
\end{array}$ \\
\hline & $\begin{array}{l}\text { Right } \\
\text { CI } \\
\end{array}$ & $\begin{array}{l}84.6 \\
8 \\
\end{array}$ & 6.04 & $\begin{array}{l}86.6 \\
6 \\
\end{array}$ & 6.18 & -1.98 & $\begin{array}{l}0.05 \\
*\end{array}$ \\
\hline
\end{tabular}

*Statistically significant difference at $\mathrm{p}$ value $\leq 0.05$ SD: standard deviation

\section{DISCUSSION}

The age of this study sample was selected between 18-24 years because the same facial dimensions were maintained till 25 years since the majority of facial growth is usually ended by the age of 16-17 years (20). 
Regarding macro-esthetic appearance, the results indicated that the mean values of both linear and vertical facial measurements (macro-aesthetic appearance) were higher in males than females. This goes in agreement with Zaghloul et al (21) and Muhammad et al (22) who performed anthropometric measurements in Egyptian adults and found that males mainly had larger facial parameters than females. This could be referred to that the human being faces have dimorphic features between sexes, especially after puberty (20). According to Shah, both genes and hormones affect the growth of human beings; the males have longer growth periods than females so that the males were having greater measurements than females (23). Only two exceptions were found, upper lip vermilion ULV and lower lip vermilion LLV values, which were higher in females group than males group. With ULV mean value of $5.83 \mathrm{~mm}$ for males group and $6.82 \mathrm{~mm}$ for females group and LLV mean value of $9.17 \mathrm{~mm}$ for males group and $10.14 \mathrm{~mm}$ for females group. It seems that the Egyptian upper lip vermilion ULV and lower lip vermilion LLV values were closer to those of the Iraqi population, Mohammed et al. (24) found in Iraqi individuals with the same age group as in the present study mean values of $5.33 \mathrm{~mm}$ for ULV and 10.11 $\mathrm{mm}$ for LLV for the male group and $5.38 \mathrm{~mm}$ for ULV and $10.29 \mathrm{~mm}$ for LLV for the female group. While Sawyer et al. (25) found that in young Caucasian subjects, all lip parameters were larger in males group than in females group, this could be attributed to ethnical differences.

In this study, an Independent t-test indicated that there were statistically significant gender differences regarding almost all measured facial variables. The only statistical non-significant gender differences were found in Inter-canthal distance ICD with mean values of 32.01 and $31.81 \mathrm{~mm}$ for male and female groups, respectively. These results were disagreed with Abdel-Rahman et al (26) who mentioned that in a sample of two hundred Egyptian healthy young individuals of both sexes, highly significant gender differences were found regarding Inter-canthal width. Other researcher found nearly similar results in different nationalities. Al-Wazzan et al (27) measured the facial dimensions using a modified Boley gauge in Saudi Arabian adults, published an ICD mean value of $31.92 \mathrm{~mm}$ with nonsignificant gender differences. El-Sheikh et al (28) published a mean value of $32.8 \mathrm{~mm}$ when they measured the ICD in Sudanese population with no significant gender differences concerning gender or age. On the other hand, Osunwoke et al (29) mentioned that in Ijaws people (Nigerian tribe), the mean values of all facial measurements were statistically significantly higher in males than females including the inter-canthal distance.

Regarding the maxillary anterior teeth measurements, the mesiodistal width of each of the maxillary central incisors, lateral incisors, and canines (MDW), combined mesiodistal width (CMW) and, total maxillary anterior teeth width (TAW) were higher in males group than females group except for mesiodistal width of lateral incisors in both sides which were higher in females group than males group. These findings were in agreement with Bishara et al (15) who found that in Egyptian individuals the mean values of the maxillary anterior teeth parameters were higher in males group than in females group and with Farag et al (30) who found that females had significantly smaller maxillary anterior teeth than males. In other populations with same age group of the present study, Mohammed et al (24) found that in Iraqi individuals the mean values of the maxillary anterior teeth parameters were higher in males group than in females group except for the mesiodistal width of left and right lateral incisor. While, Subhashini et al (31) found that in South Indian population the mesiodistal widths of the maxillary anterior dentition were larger in males group than females group including the lateral incisors mesiodestal width.

The values of the height of contact points between upper anterior teeth were higher in females group than males group. This could be due to sex-linked inheritance so that the sex-hormonal effects were suggested since genetics affect sexual dimorphism according to Garn et al (32). Additionally, there were significant gender differences regarding left central-lateral, left lateral-canine and, right lateral-canine contact points. Previously published study done by Kolte et al (33) mentioned that the mean values of all interproximal contact areas were significantly higher in males than females. It was observed that in the current study the height of the contact point between the two central incisors was the maximum among the anterior teeth, a gradual reduction was obtained on either side as the measurements progressed distally both in males and females groups. This finding is similar to that mentioned by Stappert et al (34) who found that the contact point area dimensions gradually decreased as moving posteriorly bilaterally.

Regarding the height of the central incisor, the mean values were higher in males than females. In the male group, the left central incisors were longer than the right, while in the female group there were no side differences. Independent t-test indicated that there were statistically significant gender differences regarding the height of left central incisors. Gillen et al (35) published that the maxillary anterior teeth of females were shorter than those of males in both American black and white populations. As well as, Sterrett et al (18) who recorded values of the length of the maxillary anterior teeth in males to be significantly greater than those in females among white population.

Regarding Micro-esthetic appearance, according to the present investigation in the Egyptian population, there were statistically significant gender differences except for the golden proportion and golden percentage of central and lateral incisors. The results of the current investigation also showed that both genders have higher canines' golden proportion values, while lateral incisors approximated the standard golden proportion values previously mentioned by Levin (16). Fayyad et al. (36) reported that gender is not a significant factor since the golden proportion and golden percentage values were depending on the racial or ethnic characteristics rather than gender difference. Additionally, Mahshid et al. (37) mentioned that in Egyptians, the existence of the golden proportion did not affect by the gender differences.

In the present study, it was found that the height of contact point ratio between central incisors was the maximum among the anterior teeth which gradually reduced while moving distally from the midline in both sides but smaller than that mentioned by Sarver with highly statistically significant gender differences $(\mathrm{p}<0.0001)$ but no side differences. These findings were dissimilar to those obtained by Kolte et al. (33), who 
mentioned that for all maxillary anterior teeth, the contact point ratio was more in the males than females.

Regarding maxillary central incisors width to length ratio, the mean values of both central incisors were higher in females than males; this could be attributed to longer central incisors in men. These results found to be in agreement with Hassan et al. (38), who found the mean values of maxillary central incisors width to length ratio in Egyptian adults were higher in males group than females group. Almost similar results were published in the Iraqi population by Al-Kaisy et al. (39), who found that both Arab and Kurdish Iraqi populations had significant gender differences regarding the maxillary central incisors width to height ratio.

\section{CONCLUSION}

Based on 2D digital photogrammetry, the macro-esthetic appearance, maxillary anterior teeth measurements, and the micro-esthetic appearance of Egyptian adults were analyzed, and sexual differences were obtained. In most of the macroesthetic appearance, the males have larger facial parameters than females with a significant gender difference $(\mathrm{p} \leq 0.05)$. While for most of the micro-esthetic appearance, the females have larger proportions than males with a significant gender difference $(\mathrm{p} \leq 0.05)$.

\section{REFERENCES}

1. Samorodnitzky-Naveh GR, Geiger SB, Levin L. Patients' satisfaction with dental esthetics. J Am Dent Assoc. 2007;138:805-8.

2. Goldstein RE. Esthetic principles for ceramo-metal restorations. Dent Clin North Am. 1977;21:803-22.

3. Van Loenen M, Degrieck J, De Pauw G, Dermaut L. Anterior tooth morphology and its effect on torque. Eur $\mathrm{J}$ Orthod. 2005;27:258-62.

4. Scott GR, Turner CG. Anthropology of modern human teeth. Cambridge: Cambridge University Press; 1997.

5. Hasanreisoglu U, Berksun S, Aras K, Arslan I. An analysis of maxillary anterior teeth: Facial and dental proportions. J Prosthet Dent. 2005;94:530-8.

6. Lavelle CL. Maxillary and mandibular tooth size in different racial groups and in different occlusal categories. Am J Orthod Dentofac. 1972;61:29-37.

7. Gupta L, Gupta K, Hegde V, Pradeep S, Singh P. Embodiment of Macro and Mini aesthetic elements in rehabilitation of maxillary anterior teeth with porcelain laminates veneer- A clinical report. Int J Clin Dent. 2019;12:52-9.

8. Muhammad S, Shahid R, Siddiqui MI. Tooth Morphology and Aesthetics While Smiling in Accordance to Golden Proportion. Pak J Med Health Sci. 2016;10:281-4.

9. Collier J. Visual Anthropology: Photography as a Research Method. New York: Holt, Rinehart and Wiston; 1967.

10. Isa Z, Tawfiq O, Noor N, Shamsudheen M, Rijal O. Regression methods to investigate the relationship between facial measurements and widths of the maxillary anterior teeth. J Prosthet Dent. 2010;103:182-8.

11. Becker DG, Tardy ME. Standardized photography in facial plastic surgery: pearls and pitfalls. Facial plast surg. 1999;15:93-9.
12. Dolen UC, Cinar S. Perfect lighting for facial photography in aesthetic surgery: ring light. Aesthetic plast surg. 2016;40:319-26.

13. Milutinovic J, Zelic K, Nedeljkovic N. Evaluation of Facial Beauty Using Anthropometric Proportions. Sci World J. 2014;22:21-8.

14. Proffit WR, Fields HW, Sarver DM. Contemporary orthodontics. $5^{\text {th }}$ ed. St. Louis: Mosby Elsevier; 2013.

15. Bishara S, Jakobsen J. Longitudinal changes in three normal facial types. Am J Orthod. 1985;88:466-502.

16. Levin EI. Dental esthetics and the golden proportion. J Prosthet Dent. 1978;40:244-52.

17. Snow SR. Esthetic smile analysis of anterior tooth width: the golden percentage. $\mathrm{J}$ Esthet Dent. 1999;11:177-84.

18. Sterrett JD, Oliver T, Robinson F, Fortson W, Knaak B, Russell CM. Width/length ratios of normal clinical crowns of the maxillary anterior dentition in man. J Clin Periodontol. 1999;26:153-7.

19. Sarver D, Jacobson RS. The aesthetic dentofacial analysis. Clin Plast Surg. 2007;34:369-94.

20. Rajpara Y, Shyagali T. An assessment of sexual dimorphism concerning facial asymmetry inesthetically pleasing faces. Acta Inform Med. 2015;23:44-8.

21. Zaghloul NM. Sex And Stature Determination From Maxillo-Facial Anthropometry In Adult Egyptian Population Sample. EJFSAT. 2019;19:13-28.

22. Muhammad H, Hazem AS. Vertical facial dimensions and indices in adult upper Egyptians. Am J Sci. 2011;7:785-91.

23. Shah T, Patel M, Nath S, Shobhana K. Determination of sex using cephalo-facial dimensions by discriminant function and logistic regression equations. Egypt J Forensic Sci. 2015;10:1-5.

24. Mohammed DR, Al-Sheakli I. Photographic Analysis of Macro- Aand Micro-Aesthetic Appearance in a Sample of Iraqi Adults With Class I Normal Occlusion. J Bagh Coll Dentistry. 2017;29:153-9.

25. Sawyer AR, See M, Nduka C. 3D Stereophotogrammetry Quantitative Lip Analysis. Aesthetic Plast Surg. 2009;33:497-504.

26. Abdel-Rahman RH, Amr SG, Mansoura AK. Sexual Dimorphism of Anthropometric Measurements of Periorbital Soft Tissues in a Sample of Egyptian Adults. Mansoura J Forens Med Clin Toxicol. 2019;27:122-9.

27. Al-Wazzan KL. The Relationship Between Intercanthal Dimensions and the Widths of Maxillary Anterior Teeth. J Prosth Dent. 2001;86:608-12.

28. El-Sheikh NM, Mendilawi LR, Khalifa N. Intercanthal Distance of a Sudanese Population Sample as a Reference for Selection of Maxillary Anterior Teeth Size. Sudan J Med Sci. 2010;5:117-21.

29. Osunwoke EA, Didia BC, Olotu EJ, Yerikema AH. A study on the normal values of inner canthal, outer canthal, interpupillary distance and head circumference of 3-21 years Ijaws. J Sci Ind Res. 2012;3:441-5.

30. Farag MS, Khattab NM, Refai WM. Validity of Bolton analysis among a group of Egyptian population. Egypt Dent J. 2012;58:40-7. 
31. Subhashini MH, Prasad MK, Jain AR. Incidence of golden proportion among a target South Indian population. J Pharm Res. 2018;12:20-3.

32. Garn SM, Lewis AB, Kerewsky RS. X-Linked inheritance of tooth size. J Dent Res. 1965;44:439-41.

33. Kolte AP, Kolte RA, Bawankar P. Proximal contact areas of maxillary anterior teeth and their influence on interdental papilla. Saudi Dent J. 2018;30:324-9.

34. Stappert CF, Tarnow DP, Chu SJ. Proximal contact areas of the maxillary anterior dentition. Int J Periodont Restorat Dent. 2010;30:471-7.

35. Gillen RJ, Schwartz RS, Hilton TJ, Evans DB. An analysis of selected normative tooth proportions. Int J Prosthodont. 1994;7:410-7.

36. Fayyad MA, Jamani KD, Aqrabawi J. Geometric and mathematical proportions and their relations to maxillary anterior teeth. J Contemp Dent Pract. 2006;5:62-70.

37. Mahshid M, Khoshvaghti A, Varshosaz M, Vallaei N. Evaluation of "Golden Proportion'” in Individuals with an Esthetic Smile. J Esthet Restor Dent. 2004;16:18593.
38. Hassan AZ, Shalaby Y, Osman H, El Tantawi M, Boksomaty M. Facial and dentofacial esthetic analysis in a group of Egyptian dental students. Alexandria university; Egyptian Universities Library Consortium;2010.

39. Al-Kaisy N, Garib BT. Analysis of the golden proportion and width/height ratios of maxillary anterior teeth in Arab and Kurdish populations. J Prosthet Dent. 2018;119:981-6.

40. Murthy BS, Ramani N. Evaluation of natural smile: Golden proportion, RED or Golden percentage. J Conserv Dent. 2008;11:16-21.

41. Koidou VP, Chatzopoulos GS, Rosenstiel SF. Quantification of facial and smile esthetics. J Prosthet Dent. 2015;113:198-204.

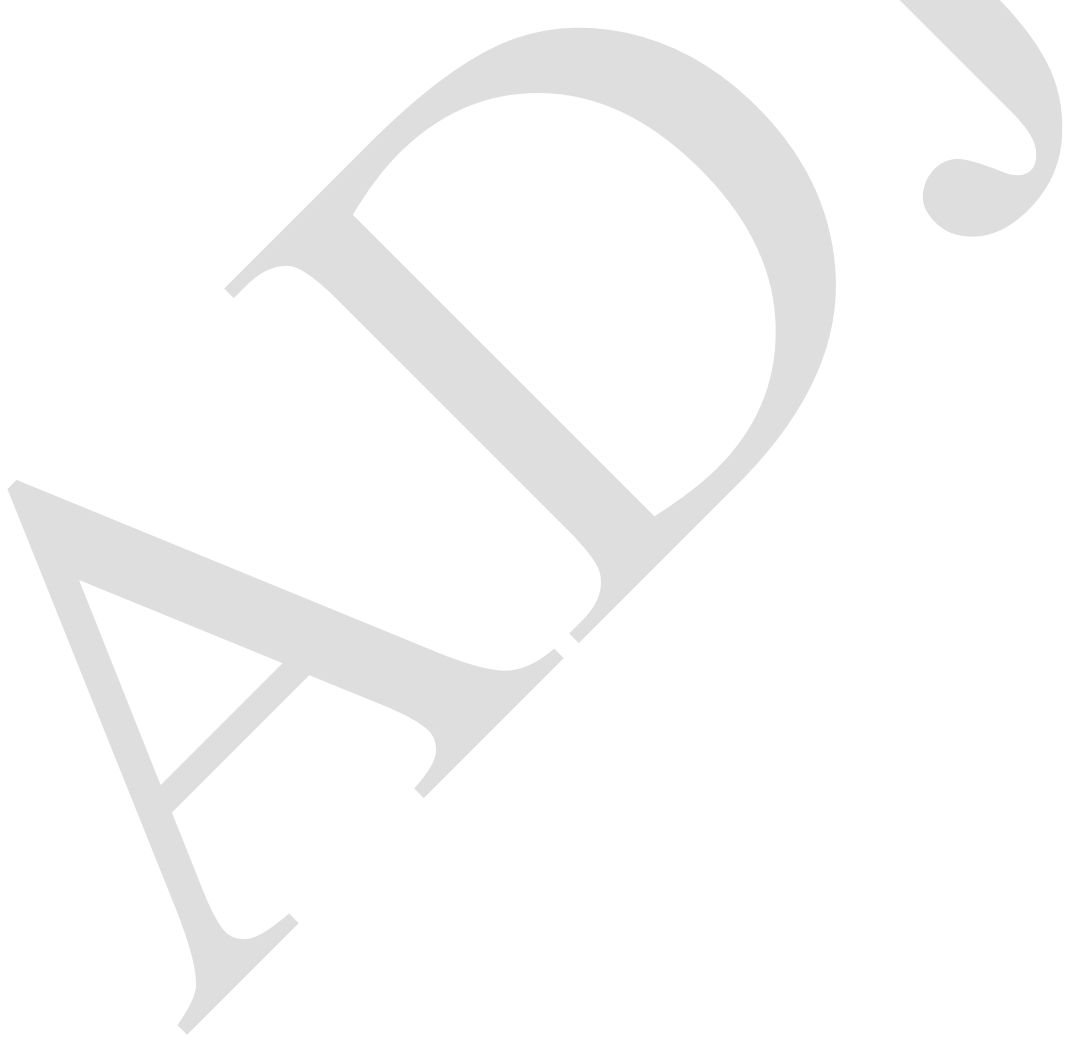

